\title{
National Savings and Fiscal Policy
}

\author{
James Cox
}

$\mathrm{T}$

Twenty years ago, excessive saving by households was considered likely to delay economic recovery by reducing consumers' expenditure. Today, a shortage of national savings is counted among Australia's economic problems. For example, in his report on savings, Dr Vince FitzGerald (1993:2) stated 'Australia's saving was consistently about 25 per cent of GDP for most of the period until the mid 1970s. Over the 1980s it fluctuated in the region of 20 per cent of GDP, but from 1989 onwards has fallen progressively, reaching a low of 16 per cent in 1991/92, its lowest level in two generations'. The report called for a national savings strategy to increase the 'underlying savings rate' by about 5 per cent of GDP over the coming decade. Government savings could be increased by reductions in outlays and increases in revenues, whereas household savings could be increased by higher contributions to the Superannuation Guarantee.

The FitzGerald report shows (pp.3,27) that the fall in national saving as a share of GDP over the past 20 years is largely due to a fall in government ('public') savings. Moreover, government saving is the more variable component. Private savings have also fallen as a share of GDP but, given the slow growth in incomes in recent years, and increases in welfare-state benefits, they have arguably held up surprisingly well. What then is the relationship between government and private saving? Some writers (e.g. Barro, 1974) have argued that taxpayers react to government deficits (negative savings) by increasing their saving in anticipation of the higher taxation (stemming from increased debt-servicing costs) or the faster inflation that will eventually occur. Yet taxpayers cannot easily obtain information about the public finances. As well, they may be less concerned about the effects on others (such as their children or the young generally) than those on themselves. So whereas changes in private savings are likely to offset changes in government savings to some extent, the significance of this offset remains controversial.

What is certain is that the decline in government savings has been the most important factor in explaining the reduction in national savings.' Based on national accounts data (ABS, 1993a,b) the correlation coefficient between national savings and general government savings is 0.87 . So around three-quarters of changes in total saving can be 'explained' by changes in the saving of the general government sector.

\footnotetext{
' 'Saving' here means the total finance of gross accumulation for the relevant sectors.
} 


\section{Figure 1}

\section{Combined government sector: current outlays, revenue and sav- ings as shares of GDP, 1961-94}

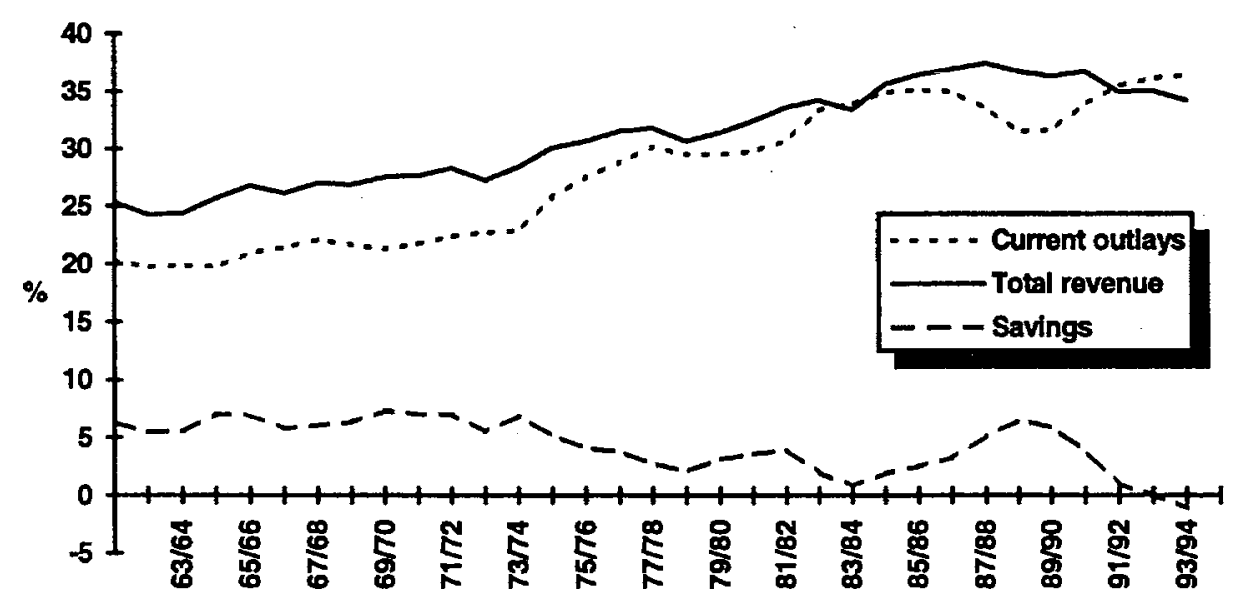

Source: ABS (1993c).

\section{Government Saving}

Government (or public-sector) saving is here defined as the difference between current outlays and current revenues. The consolidated accounts of both the general government sector and the public trading enterprise sectors of all governments show the effects of changes in the pricing policies of public enterprises. The ABS has classified the expenditures, revenues and financing transactions of all Australian governments (Commonwealth, State, Territory and local) from 1961/62 on a consistent basis. Data from 1988/89 to 1993/94 have been published (ABS, 1993c), and unpublished data for the earlier years are now available from the ABS (for a substantial fee).

Figure 1 presents data on current outlays (the sum of final consumption expenditure, interest payments, subsidies to public enterprises and transfer payments), total revenue (taxes, fines and fees, the net operating surplus of public trading enterprises, interest received and other revenue), and the balance on current transactions, which is taken here to be the measure of government savings. ${ }^{2}$ In Figure 1,

2 The balance on current transactions is measured by subtracting current outlays from the total of revenue plus increase in provisions minus capital revenue. 'Provisions' include public-trading enterprise provisions for depreciation, and provision for superannuation, long-service leave and the like. See ABS (1993c) for further information. 
the data for 1992/93 are preliminary; those for 1993/94 are based on forward estimates and should be used with particular caution.

As Figure 1 shows, before 1974/75, current government outlays were around 20-23 per cent of GDP, revenues 25-28 per cent, and government savings 5-7 per cent. Current outlays then increased sharply to 30 per cent of GDP by 1977/78. Despite an increase in revenues, government saving declined to 2 per cent of GDP by $1978 / 79$.

Outlays remained at about 30 per cent of GDP between 1977/78 and 1981/82. Government savings recovered to 4 per cent of GDP by $1981 / 82$, significantly below the level achieved before 1974/75. In 1982/83, current outlays surged again, to 33 per cent of GDP.

Current outlays stabilised and then fell to 31.5 per cent of GDP by 1989/90. Government savings reached 6.5 per cent of GDP by 1988/89. Since 1988/89, outlays have risen again, and are estimated to have been 36 per cent of GDP in 1992/93. Meanwhile, revenues have fallen as a share of GDP, resulting in low levels of government saving; indeed, government savings are expected to be negative in 1993/94.

The record shows that, as current government outlays have risen as a share of GDP over the past 20 years, government savings have fallen. The correlation coefficient between government savings and government current outlays as shares of GDP was -0.82 between $1961 / 62$ and $1993 / 94$, which suggests that two-thirds of the variation in government savings over the period was associated with the variation in current outlays. By contrast, the correlation between savings and revenue over the same period was -0.60 . Government savings tended to be lower as a share of GDP in those (later) periods when revenues were higher as a share of GDP than in those periods when revenues were lower.

Anguably, government spending on health and education should be treated as investment in human capital (a kind of saving) rather than current expenditure. But, as such spending has increased rapidly, this would be to redefine into nonexistence much of the government (and national) saving problem. The growth in government health spending has largely replaced private expenditure: Medicare has partly replaced private health insurance, for example. It is also doubtful whether much health and education expenditure is really investment. So it seems unreasonable to treat government education and health expenditure as an addition to national saving, although an (unknown) proportion of it may be so.

\section{Explaining Short-Term Changes}

How can these developments be explained? Two levels of explanation seem relevant here: for the annual changes in outlays, revenue and savings as a share of GDP, and for the long-term changes that have occurred over the decades.

Changes in political and economic circumstances seem to be responsible for the year-to-year movements in these data series. In a study of the effect of elections on the Commonwealth budget, Gruen (1985: ii-iii) concluded that 
On average real outlays increased by 5.1 per cent in election budgets compared to around half that level in pre-election budgets. In election years, there are typically tax concessions averaging around 1.8 per cent of revenue - compared to discretionary tax increases of 2.3 per cent in pre-election years. . . The two budgets which preceded the loss of office by the two Liberal Prime Ministers produced large outlay increases.

Although we are here concerned with the total public sector rather than just the Commonwealth budget, our data confirm that in the election periods of 1972/73 and 1983/84 public saving declined significantly as a share of GDP. The closely contested federal elections in 1990 and 1993 may also have tended to reduce public savings in those years and the immediately following ones. Political competition also occurs at State and local-government levels, and closely fought elections there may also have some effect on public savings.

Recessions tend to increase government outlays (for example, on unemployment and other benefits) but to reduce revenue and GDP. They therefore increase the share of outlays in GDP but have an ambiguous effect on the ratio of revenue to GDP. Years in which there has been an upsurge of unemployment (1974/75, $1976 / 77,1982 / 83,1990 / 91,1991 / 92)$ have seen an increase in government outlays and a reduction in government savings as a share of GDP.

\section{Explaining Medium-Term Changes}

Political influences and changing macroeconomic circumstances are less satisfactory as explanations for medium-term changes. After all, the fiscal damage done by election budgets can be subsequently repaired if there is the will to do so. Although an upsurge in unemployment may lead to an immediate increase in government spending, governments may be able to take advantage of subsequent quieter periods to reduce other items of spending (or increase taxes). Any reluctance on the part of governments to do these things needs to be explained.

As already observed, outlays have increased as a share of GDP throughout the period under discussion. Revenues increased until the mid-1980s but were lower as a share of GDP during the early 1990s than during the late 1980s. Government savings tended to be highest during the 1960s when the outlays share was at its lowest and during the 1980s when growth in outlays was restrained. Government savings were at their lowest when the outlays share was increasing rapidly or when (during the early 1990s) the revenue share was falling.

Governments seem to have become increasingly unwilling to raise revenues sufficiently to finance higher levels of current spending. (The introduction of a new, more efficient, tax such as the GST might possibly restore the appetite for tax increases.) Two influences seem to be at work here: a limit to the extent to which governments are prepared to increase taxes in any one year; and (more speculatively) a limit to the total amount of revenue that governments are willing to collect.

Over the 31 years from 1962/63 to 1993/94 (forward estimates) the revenue 
share of GDP increased year-on-year by over 1 per cent in only six years and by over 1.5 per cent in only two years (1974/75 and 1984/85). Governments seem unwilling to increase revenue in any one year beyond 1-1.5 per cent of GDP. The permissible increase may depend on income growth: the faster incomes are growing, the larger is the acceptable increase in revenue. Yet the revenue share declined slightly during the prosperous late-1980s, and had increased during previous recession years $(1974 / 75,1982 / 83)$.

Evidence for the existence of a limit to the revenue share in GDP comes from the late 1980 s and early 1990 s, when the 25 -year trend towards a higher revenue share was reversed. The revenue share peaked at 37.4 per cent of GDP in 1987/88, but is projected (on the basis of forward estimates) to be 34.2 per cent of GDP in 1993/94. The changes proposed in the Commonwealth budget are expected to increase the revenue share by 1.4 per cent of GDP above the level that would otherwise have been achieved. (Allowing for economic growth, the revenue share in GDP is expected to grow by around 1 per cent of GDP between 1993/94 and 1996/97.) These fairly modest proposals have proved to be controversial.

Perhaps the argument about the limit to the revenue share overinterprets what was really just an accidental sequence of events, and the upward trend of revenue share may reassert itself. The first year of the next Commonwealth parliament might be a good time to review whether the revenue share has surpassed its previous peak. Yet the idea of a limit to the revenue share of GDP is a useful simplification. The cost of taxation to an individual in terms of opportunities forgone is likely to increase more than proportionately with the amount of revenue collected. A given level of taxation is more burdensome for some taxpayers than for others; but if taxation is severe enough it will become salient as a political issue. The level of income at which this occurs is not fixed but depends on the methods of tax collection and the distributional impact of taxation and the spending that it finances. Taxation, however, has undoubtedly been an important factor in recent Australian elections.

In a famous article, Colin Clark (1945:380) reviewed data on the share of taxation in national income and inflation in several countries during the inter-war period and concluded that

the data appear to give very considerable support to the hypothesis that once taxation has exceeded 25 per cent of the national income (20 per cent or less in some countries) influential sections of the community become willing to support a depreciation in the value of money; while so long as taxation revenue is below this critical limit, the balance of forces favours a stable, or occasionally an increasing, value of money.

\footnotetext{
${ }^{3}$ It is true that most other OECD countries raise a larger share of GDP in revenue than Australia does. But most other OECD countries have a broad-based consumption tax, which Australia lacks. Because Australia has a targeted age pension system, the distributional impact of government expenditure is likely to be different in Australia from that in the countries that raise in taxation (and spend) a higher percentage of GDP. That is also likely to be relevant.
} 
Clark was assuming that important elements of public expenditure (such as interest on the public debt) would not respond fully or immediately to an upsurge of inflation. Unanticipated inflation would then be one way to reduce the share of govemment spending, and hence taxation, in GDP. Other methods (such as electoral competition) must be used in modem conditions when important elements of public expenditure are governed by indexation commitments and where inflation interacts with progressive tax scales to increase government revenue in real terms. Clark's data were collected, moreover, before the introduction of innovations such as PAYE, which have made it easier to collect a large share of GDP in taxation. Even so, the idea of an upper limit to the amount of income that taxpayers will permit governments to collect in revenue is a suggestive one."

If governments find it hard to collect much more than 35 per cent of GDP in revenue, they will need to show great restraint in spending if they are to continue to meet their savings targets. This effort will need to be more sustained than any that has been mounted over the past 30 years. Governments could usefully emphasise this in response to the pressure for greater spending that undoubtedly exists. The FitzGerald report, in contrast, seemed to emphasise taxation increases rather than reductions in government current spending. Perhaps this is the wrong emphasis.

\section{What About Private Savings?}

The FitzGerald report suggested that private savings should be raised through increases in compulsory contributions under the Superannuation Guarantee. As it stands, the Superannuation Guarantee is projected to increase national savings by 0.75 per cent of GDP within ten years and by 1 per cent within 20 years. The report proposed increasing this amount to well over 1.5 per cent of GDP in ten years and ultimately to over 2 per cent.

This raises a number of issues. First, should governments have national savings goals, or is this something best left to individuals and families to decide for themselves? And is it in the interests of governments to politicise something so important to people's long-term economic welfare as private savings? What will happen when some superannuation plans turn out, as some surely must, to be poor longterm investments?

If governments are concerned about the effects of age pensions on private savings, it may be better to re-examine the conditions under which pensions are paid than to add regulation to regulation. For example, the age of eligibility for the age pension could be increased - as the FitzGerald report itself recommends.

Second, the goals the FitzGerald report suggests for adoption and the process for adopting them are both questionable. The report suggests that governments should compel people to save enough to provide themselves with a retirement income equal to 60 per cent of their pre-retirement earnings. This benchmark is selected by comparison with what happens in some overseas countries. Its implemen-

4

Clark (1945:372) attributes the idea to Keynes. 
tation would require contributions in the order of 18 per cent of pre-tax earnings. The report recognises (p.57) the importance of further public discussion before goals are set for superannuation and the age pension. Nevertheless, a retirement contribution of 18 per cent of earnings would be a heavy burden for the young who would be required to finance not only their own retirement but also that of the current retired generation. The young (and especially those with children) might well consider that current expenditure is a higher priority than a more comfortable retirement. Any retirement goal should therefore be chosen by the community in full knowledge of the substantial costs that might be involved.

Third, how effective is the Superannuation Guarantee likely to be in boosting private savings? The FitzGerald report (p.51) notes that

the Superannuation Guarantee cannot effectively serve its retirement income objectives in the face of rapid aging of the population unless it raises national saving, so as to finance ahead of time a build up of the capital stock per employee in the economy ... The key element producing increased saving - over the longer term - through the Superannuation Guarantee is that it is compulsory, raising the saving of many that without it would not be saving much in any form.

Dr FitzGerald argues that, because it is compulsory, the Superannuation Guarantee can increase the total amount that an individual saves over his or her lifetime. He notes (p.24) that 'below the seventh decile of gross income there are very low financial savings' and that 'for a substantial proportion of Australian households 35 per cent to 50 per cent - consumption is constrained by current income' (i.e. they spend all the income they receive).

The problem is that the Superannuation Guarantee will be successful only if it raises savings over the whole of the working lifetime; but the evidence refers only to whether or not the Guarantee will increase the savings of particular people in a particular year. It may well be true that one-third to one-half of households spend all their income in any year. A compulsory program can increase the amount that these people save in the year. But it is by no means certain that it is the same onethird to one-half of the population who spend all their income in every year. Indeed, there are stages in life when many people spend most of their income (for example, when young children are present in the household) and others when they are able to build their financial assets. If people have been required to save more than they wanted to in earlier years, they may well save less than they otherwise would have done in later years. The effect of the Guarantee on national savings may therefore be dissipated. Equally, people may be able to borrow against their accumulating superannuation assets to support consumption or to purchase nonfinancial assets such as housing.

On the other hand, if people believe that the Superannuation Guarantee will provide adequate provision for their old age, governments may find it easier to take 
action that will have an effect on savings, such as raising the age at which the (unfunded) age pension is payable.

It remains to be seen whether governments can require people to save more than they otherwise would have done. Compulsory savings may cause hardship to some families who have to reduce spending on necessities in consequence. It is surprising that the equity implications of compulsory superannuation have not received more attention.

\section{Conclusion}

It is hard for governments to induce people to save more than they otherwise would have done, and, in current circumstances, to increase the share of GDP that is paid in taxes. If governments are concerned about the low level of national savings, the most effective remedy would be to reduce public spending on items that substitute for private savings (like raising the age of eligibility for the age pension), though they may be constrained by the political and social consequences of such changes. And economic recovery will boost national savings by reducing current unemploymentrelated spending. Even so, low levels of national savings may persist for some years.

\section{References}

Australian Bureau of Statistics (ABS) (1993a), National Expenditure, Income and Product, 1961-62, Canberra (Cat. No. 5204.0).

(1993b), National Expenditure, Income and Product, September Quarter 1993, Canberra (Cat. No. 5206.0).

- (1993c), Government Financial Estimates, Australia, 1993-94, Canberra (Cat. No. 5501 .0).

Barro, R. (1974), 'Are Government Bonds Net Wealth?', Journal of Political Economy 82: 1095-117.

Clark, C. (194.5), 'Public Finance and Changes in the Value of Money', Economic Journal 55: 371-89.

Commonwealth of Australia (1993), Budget Statements, 199394, AGPS, Canberra.

FitzGerald, V. (1993), National Saving: A Report to the Treasurer, AGPS, Canberra.

- \& I. Harper (1993), 'Super preferred or level playing field? Implications for saving and the financial system', pp.12370 in J. Head (ed.), Fighthack' An Economic Assessment, Australian Tax Research Foundation, Sydney (Conference Series No. 12).

Gruen, F. (1985), The Federal Budget: How Much Difference Do Elections Make?, Centre for Economic Policy Research, Australian National University (Discussion Paper No. 120). 